\title{
Allergic contact dermatitis among construction workers detected in a clinic that did not specialize in occupational dermatitis
}

\author{
Dermatite alérgica de contato entre pedreiros, num serviço não especializado \\ em dermatoses ocupacionais
}

\author{
Rosana Lazzarini ${ }^{1}$ \\ Juliana Mayumi Sumita ${ }^{3}$
}

\author{
Ida Alzira Gomes Duarte \\ Rogério Minnicelli ${ }^{4}$
}

\begin{abstract}
BACKGROUND: Contact dermatitis is one of the common work-related dermatoses. Among bricklayers, cement can cause both allergic contact dermatitis and primary contact irritative dermatitis. The personal protective equipment (rubber gloves) may favor the development of allergic contact dermatitis.

ОвјестіVES: 1) to evaluate the frequency of allergic contact dermatitis among construction workers between January 2005 and December 2009; 2) to determine the major sensitizing agents in the study group; and 3) to compare the data obtained from the construction workers to that of a group of patients who were not construction workers.

METHODS: A retrospective analysis of patch tests. Patients were separated into two groups: 1) bricklayers and 2) non-bricklayers.

RESUlTS: Of the 525 patch tests analyzed, 466 (90\%) were from non-bricklayers and 53 (10\%) from bricklayers. The hands were affected in 38 (61\%) of them. 13 patients (24\%) had irritative contact dermatitis and 40 (76\%) had allergic contact dermatitis. The group of construction workers had a high frequency of sensitization to cement, and 29 (54.7\%) had sensitization to rubber vulcanizing agents. 23 patients $(43.4 \%)$ had sensitization to both cement and rubber.

ConClusions: Among the bricklayers the presence of allergic contact dermatitis to rubber and cement in the same patient is common and demonstrates the importance of the patch test.

Keywords: Dermatitis, allergic contact; Occupational diseases; Potassium dichromate; Rubber
\end{abstract}

Resumo: FundAmENTOS: A dermatite de contato é uma das dermatoses comumente relacionadas ao trabalho. Entre os pedreiros o cimento pode causar tanto a Dermatite Alérgica de Contato quanto a Dermatite de Contato por Irritação Primária. Os equipamentos de proteção individual (luvas de borracha) podem favorecer o desenvolvimento de Dermatite Alérgica de Contato.

OBjetivos: 1) avaliar a freqüência de Dermatite Alérgica de Contato entre os pedreiros entre Janeiro de 2005 e Dezembro de 2009; 2) determinar os principais agentes sensibilizantes; e 3) comparar os resultados obtidos entre o grupo de pedreiros com um grupo sem pedreiros.

MÉTodos: análise retrospectiva de testes de contato. Pacientes foram separados em 2 grupos: 1) pedreiros e 2) não pedreiros.

RESUltADOS: dentre os 525 testes de contato analisados, 466 (90\%) eram de não pedreiros e 53 (10\%) de pedreiros. As mãos foram acometidas em 38 (61\%). 13 pacientes (24\%) tinham Dermatite de Contato por Irritação Primária e 40 (76\%) tinham Dermatite Alérgica de Contato. O grupo de pedreiros apresentou alta freqüência de sensibilização ao cimento, e $29(54,7 \%)$ tinham sensibilização a agentes vulcanizadores da borracha. 23 pacientes $(43,4 \%)$ pedreiros tinham sensibilização tanto ao cimento quanto à borracha.

CONCLusões: entre os pedreiros a presença de Dermatite Alérgica de Contato ao cimento e à borracha no mesmo paciente foi comum e demonstrou a importância do teste de contato.

Palavras-chave: Borracha; Dermatite alérgica de contato; Dicromato de potássio;

Doenças profissionais

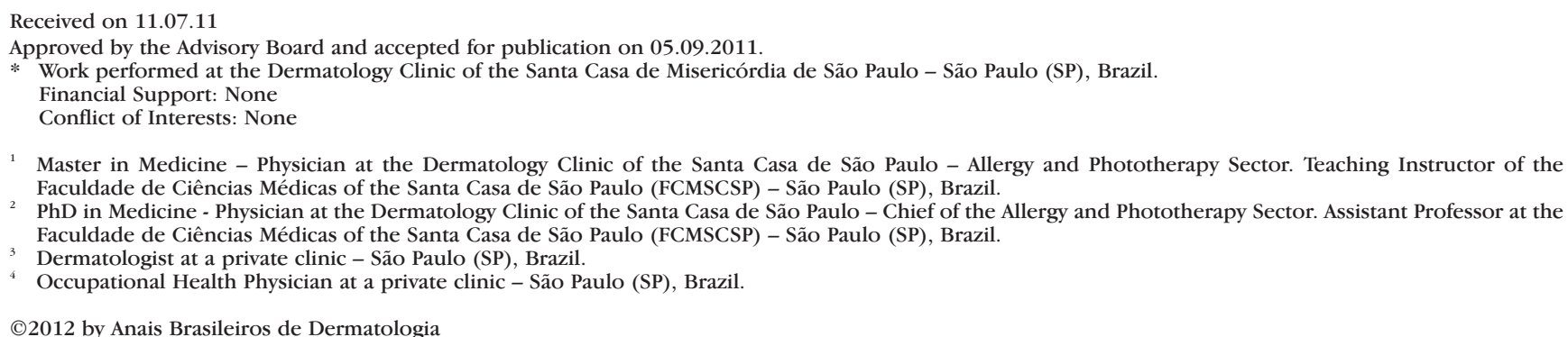




\section{INTRODUCTION}

The construction industry has emerged as a major sector of the national economy in Brazil. Moreover, due to its characteristics, the construction industry generates occupational risk that results in high rates of work accidents and occupational diseases.

Contact dermatitis is one of the most common work-related dermatoses, where cement and rubber are the major etiological agents.

Cement is a hydraulic binder that is used in the construction industry, and Portland cement is the most commonly used cement in this region. It is composed of silicon, calcium, magnesium and iron oxides, and also contains alkali and sulfur oxides. ${ }^{1}$ The wet cement becomes an abrasive and alkaline agent with a $\mathrm{pH}>10$ and leads to irritant contact dermatitis (ICD). The ability of the cement to generate allergic contact dermatitis (ACD) is associated with the presence of hexavalent chromium; the development of ACD may also have a genetic basis.

Chromium in concrete has two sources: the raw material from which the cement is produced and the red bricks that make up the furnace where the cement is produced. The amount of chromium varies in different countries. ${ }^{2}$

The use of personal protective equipment (rubber gloves) on moistened skin or previously injured skin can promote the development of minor dermatitis, such as ACD, in response to the protective equipment. In these cases the agents used in the process of vulcanization of rubber are the antigens responsible for the sensitization. ACD worsens and delays the diagnosis of occupational disease in these patients.

This study aimed to accomplish the following: 1) to evaluate the frequency of allergic contact dermatitis among construction workers who were treated at the Sector of Allergy and Phototherapy, Dermatology Clinic, Santa Casa de São Paulo, between January 2005 and December 2009; 2) to determine the major sensitizing agents in the study group; and 3) to compare the data obtained from the construction workers to that of a group of patients who were not construction workers and were treated during the same period.

\section{STUDY DESIGN AND METHODS}

A convenience sample of patch tests performed in the Dermatology Clinic of Santa Casa de São Paulo, between January 2005 and December 2009 were evaluated retrospectively. Patients were separated into two groups: 1) bricklayers and 2) non-bricklayers.

Patients were submitted to patch tests that utilized the Brazilian Standard Series (FDA-Allergenic RJ/Brazil), which were applied using the FINN
Chambers (Oy, Finland) technique. We considered the readings after 96 hours according to the criteria of the International Contact Dermatitis Research Group (ICDRG).

The results were recorded in an Excel $^{\circledR}$ spreadsheet and were compared using the chi-square test.

\section{RESULTS}

Between January 2005 and December 2009, patch tests were performed in $\mathbf{5 2 5}$ patients who had been diagnosed with allergic contact dermatitis in the Sector of Allergy and Phototherapy of the Dermatology Clinic, Santa Casa de São Paulo. Of this group, 466 patients (90\%) had other occupations (non-bricklayers), whereas 53 patients (10\%) were construction workers (bricklayers). Six cases were excluded due to a lack of identification of their occupation.

The 53 bricklayers included in the study were male; their mean age was 47 years with a median of 48.5 years, which ranged from 30 to 49 years old.

Of the 53 bricklayers, 50 (94\%) presented to the clinic with more than four months of clinical symptoms, whereas the remaining $3(6 \%)$ presented with less than four months of clinical symptoms.

The hands were affected in 38 patients (61\%), the feet were affected in 25 patients (42\%), and the forearms were affected in 13 patients (21\%). In addition, more than one area was affected in some patients.

In the group of 53 bricklayers, 13 patients (24\%) underwent patch tests that yielded either negative or positive results that were not relevant to the dermatoses; these 13 cases were thought to involve ICD (95\% confidence interval $=13 \%-35 \%)$. The other 40 patients $(76 \%)$ had at least one positive patch test reaction that was relevant to the activity performed, which confirmed the ACD diagnosis (95\% confidence interval $=65 \%-87 \%$ ).

Sensitization to cement was demonstrated with positive reactions to potassium dichromate in 34 patients (64\%) in the bricklayer group. Sensitization to potassium dichromate occurred in 26 of the patients $(5.6 \%)$ in the non-bricklayer group. The difference in the number of positive potassium dichromate tests between the two groups was statistically significant $(\mathrm{p}<0.001)$. The bricklayer group showed a greater sensitivity to potassium dichromate (Table 1).

Sensitization to cobalt chloride was observed in 19 patients (35.8\%), in the bricklayer group. Statistical analysis showed that the number of sensitized individuals was higher among the bricklayers compared to the non-bricklayers $(\mathrm{p}<0.001)$.

In the bricklayer group, 29 patients (54.7\%) had 
TABLE 1: Results from the contact tests to potassium dichromate

\begin{tabular}{|c|c|c|c|c|}
\hline \multirow[t]{2}{*}{ Occupation } & & \multicolumn{2}{|c|}{ Potassium dichromate } & \multirow[t]{2}{*}{ Total } \\
\hline & & Negative & Positive & \\
\hline \multirow[t]{2}{*}{ Non-bricklayer } & $\mathrm{n}$ & 440 & 26 & 466 \\
\hline & $\%$ & 94,4 & 5,6 & 100,0 \\
\hline \multirow[t]{2}{*}{ Bricklayer } & $\mathrm{n}$ & 19 & 34 & 53 \\
\hline & $\%$ & 35,8 & 64,2 & 100,0 \\
\hline \multirow[t]{2}{*}{ Total } & $\mathrm{n}$ & 459 & 60 & 519 \\
\hline & $\%$ & 88,4 & 11,6 & 100,0 \\
\hline
\end{tabular}

$\mathrm{p}<0,001$ (chi-square test)

positive reactions to one of the rubber vulcanizing agents. Among the non-bricklayer group, sensitization to rubber vulcanizing agents occurred in 85 patients (18.2\%). The number of positive tests for the rubber vulcanizing agents was higher among the bricklayer group and this difference was statistically significant $(\mathrm{p}<0.001)$ (Table 2).

Among the bricklayers group, table 3 shows that 23 patients (43.4\%) had positive reactions to both cement and at least one of the rubber vulcanizing agents. There were individuals who were sensitive to cement and a rubber vulcanizing agent among the non-bricklayers, but this occurred in only 12 patients (2.6\%). The difference between the two groups was statistically significant $(\mathrm{p}<0.001)$.

Positive tests for the following rubber vulcanizing agents were obtained in several bricklayer patients: Carba, 24 patients (45.3\%); Thiuram, 18 patients (34\%); PPD, 9 patients (17\%); and MBT, 4 patients (7.5\%). In addition, some patients had more than one positive test.

Other positive patch tests among the bricklayers included the following: nickel sulfate, 9 patients (17\%); epoxy resin, 4 patients (7.5\%); neomycin, 8 patients (15\%); ethylenediamine, 6 patients (3\%); quaternium-15, 3 patients (6\%); quinoline, 2 patients (4\%); and lanolin and promethazine resulted in posi- tive patch tests in 1 patient each (2\%). It is important to note that all patients showed more than one positive test.

In terms of the sensitization to nickel sulfate, $17 \%$ of the bricklayers showed positive results, whereas $33 \%$ of the non-bricklayers showed positive results $(\mathrm{p}=0.018)$.

\section{DISCUSSION}

The bricklayer occupation, especially in Brazil, consists of a group of less skilled workers who start the occupation without previous training; this situation facilitates the emergence of occupational dermatitis.

There are many health and social problems faced by this population and contact dermatitis precipitates or aggravates pre-existing dermatoses.

The most frequent site of dermatitis include the hands, which were the affected site in $61 \%$ of the cases and this is consistent with the report by Bock et al. that involved this type of workers; other frequently affected sites were the legs and the forearms. ${ }^{3}$ In Brazil, the bricklayers do not always use appropriate clothing and footwear, which can also expose the feet to occupational dermatitis.

The use of protective equipment may have contributed to the decrease in the frequency of ICD.

TABLE 2: Results from the contact tests to rubber

\begin{tabular}{lllll}
\hline Occupation & & $\begin{array}{l}\text { Rubber } \\
\text { Negative }\end{array}$ & Positive & Total \\
\hline \multirow{2}{*}{ Non-bricklayer } & $\mathrm{n}$ & 381 & 85 & 466 \\
\multirow{2}{*}{ Bricklayer } & $\%$ & 81,8 & 18,2 & 100,0 \\
\multirow{2}{*}{ Total } & $\mathrm{n}$ & 24 & 29 & 53 \\
& $\%$ & 45,3 & 54,7 & 100,0 \\
& $\mathrm{n}$ & 405 & 114 & 519 \\
& $\%$ & 78,0 & 22,0 & 100,0 \\
\hline
\end{tabular}

$\mathrm{p}<0,001$ (chi-square test) 
TABLE 3: Results from the contact tests to rubber and cement

\begin{tabular}{llllll}
\hline Occupation & & \multicolumn{3}{c}{ Cement and rubber } & \multirow{2}{*}{ Total } \\
\cline { 3 - 5 } & & $\begin{array}{l}\text { Negative tests } \\
\text { to both }\end{array}$ & $\begin{array}{l}\text { Positive tests to } \\
\text { one of them }\end{array}$ & $\begin{array}{l}\text { Positive tests } \\
\text { to both }\end{array}$ & \\
\hline Non-bricklayer & $\mathrm{n}$ & 367 & 87 & 12 & 466 \\
Bricklayer & $\%$ & 78,8 & 18,7 & 2,6 & 100,0 \\
Total & $\mathrm{n}$ & 13 & 17 & 23 & 53 \\
& $\%$ & 24,5 & 32,1 & 43,4 & 100,0 \\
& $\mathrm{n}$ & 380 & 104 & 35 & 519 \\
& $\%$ & 73,2 & 20,0 & 6,7 & 100,0 \\
\hline
\end{tabular}

$\mathrm{p}<0,001$ (chi-square test)

Moreover, protective equipment, in addition to other factors, contributed to the $64.2 \%$ incidence of ACD. Another factor is the high concentration of hexavalent chromium contained in Brazilian cement, which favors the development of ACD. ${ }^{4,5}$ Some studies showed a decrease in the frequency of ACD in response to cement in countries where iron was introduced to the cement. This element promotes the reduction of the hexavalent chromium to the trivalent form, which has a reduced potential to cause hypersensitivity reactions. ${ }^{6}$

Cobalt is a metal that is considered a co-sensitizing agent with chromium. ${ }^{7}$ The penetration of cobalt into the skin is facilitated by the action of chromium. The current study revealed a high frequency of individuals who were sensitized to cobalt, and this was probably related to the high rates of sensitization to chromium.

Rubber was a common sensitizing agent among the workers. This was probably due to the use of rubber gloves, which is the main personal protective equipment (PPE) used by these workers. Other rubber PPEs, such as boots and earmuffs, can also cause contact dermatitis among construction workers. In this study, the level of sensitization to rubber was higher among the bricklayers compared to that observed in the general population. These findings were consistent with previous data that showed high levels of sensitization in individuals who use rubber gloves to protect a previously injured area; the use of rubber gloves promoted the accumulation of moisture and facilitated maceration.

The main sensitizers related to rubber included the carbamates and thiuram. The thiuram group of compounds is the main accelerator in the process of rubber vulcanization. The carba group is also used as an accelerator of the vulcanization process, and its chemical similarity to the thiuram group often generates cross-reaction in patch tests. ${ }^{2}$
Concomitant sensitization to cement and rubber occurred in 23 patients (43\%), which is consistent with the results observed by Condé-Salazar et al. in 1995. ${ }^{8}$

Nickel is a contaminant of cement and exists in an insoluble form as nickel oxide ( $\mathrm{NiO})$. In this form, it is unable to cause sensitization. There were 9 patients (17\%) with positive reactions to nickel sulfate, and these workers were exposed to nickel sulfate from a source other than cement. ${ }^{2,4}$ Nickel was one of the main sensitizers in the general population; therefore, the presence of positive nickel tests among these bricklayers was probably not related to their professional activities.

The test for the sensitization to epoxy resin was positive in two patients, and sensitization is associated with the construction industry due to paints and concrete, but it can also be associated with the manufacture of decorative objects and personal adornment. 2 Its use in this sector has grown, especially in European countries, bringing as a consequence the increase in the frequency of awareness among workers. Unlike what happens with the chromium in cement, the epoxy resin sensitization occurs in a short time. ${ }^{9}$ There are insufficient data on the frequency of sensitization to this allergen in our environment.

Other common sensitizers among bricklayers included topical medications. The tests were positive for either the active ingredients (neomycin, quinoline and promethazine) or to other components of the formulations (ethylenediamine, lanolin and quaternium15). This was probably due to the use of various topical medications on previously damaged areas of the body, which favored the penetration and sensitization to additional allergens.

\section{CONCLUSIONS}

Contact dermatitis is a skin condition that is common among bricklayers; their hands were the 
main location affected by this condition. Chromium was the most frequent sensitizer in this group; however, the association of ACD with cement and rubber in the same patient illustrated the importance of the patch test. Furthermore, if not identified, secondary sensitization due to the use of topical medications often delays the patients' recovery.
Despite the use of protective equipment, contact dermatitis remains a common dermatosis in construction workers.

In conclusion, the clinical context and the patch tests help in the etiologic diagnosis of this dermatosis.

\section{REFERENCES}

1. Abcp.org.br [Internet]. Associação Brasileira de Cimento Portland [acesso 17 Jul 2010]. Disponível em: http://www.abcp.org.br/conteudo/wpcontent/uploads/2009/12/press_kit.pdf .

2. Avstorp C. Cement. In: Kanerva L, Elsner P, Wahlberg JE, Maibach HI, editors. Condensed Handbook of Occupational Dermatology. Berlin: Springer; 2004. p.339.

3. Bock M, Schmidt A, Bruckner T, Diepgen TL. Occupational skin disease in the construction industry. Br J Dermatol. 2003;149:1165-71.

4. Ali AS. Dermatoses ocupacionais. 2 ed. São Paulo: Fundacentro; 2009.

5. Ignati BI. Comunicação pessoal. Teores de cromo e níquel em cimentos no Brasil. In: Ali AS, editor. Dermatoses ocupacionais. São Paulo: Fundacentro; 2009. p. 88.

6. Johansen J, Menné T, Christophersen J, Kaaber K, Veien N. Changes in the pattern of sensitization to common contact allergens in Denmark between 1985-86 and 199798, with a special view to the effect of preventive strategies. $\mathrm{Br} J$ Dermatol. 2000;142:490-5.

7. Sarma N. Occupational allergic contact dermatitis among construction workers in India. Indian J Dermatol. 2009;54:137-41.
8. Condé-Salazar L, Guimaraens D, Villegas C, Romero A, Gonzalez MA. Occupational allergic contact dermatitis in construction workers. Contact Dermatitis. 1995;33:226-30.

9. Geier J, Krautheim A, Uter W, Lessmann H, Schnuch A. Occupational contact allergy in the building trade in Germany: influence of the preventive measures and changing exposure. Int Arch Occup Environ Health. 2011;84:403-11.

\section{MAILING ADDRESS: \\ Juliana Mayumi Sumita}

Rua Dr. Cesário Mota Júnior, 112, ED. Conde Lara

$5^{\circ}$ Andar - Vila Buarque

01221-020 São Paulo, SP

E-mail: juliana.sumita@gmail.com

How to cite this article: Lazzarini R, Duarte IAG, Sumita JM, Minnicelli R. Allergic contact dermatitis among construction workers detected in a clinic that did not specialize in occupational dermatitis. An Bras Dermatol. 2012;87(4):567-71. 